\title{
ФОРМУВАННЯ МИСЛЕННЯ СУЧАСНОГО ВИКОНАВЦЯ В СИСТЕМІ ІНТЕГРАЛЬНИХ ЗВ'ЯЗКІВ ТЕОРІЇ МУЗИКИ ТА ІНТЕРПРЕТОЛОГІЇ
}

\author{
Александрова О. О., Шаповалова Л. В.
}

\section{ВСТУП}

Музична наука, яка за всі часи слугувала узагальненню законів звукообразного буття людини, на сучасному етапі характеризується численністю творчих практик, а відтак багатовимірністю, відкритістю до нових гуманітарних дискурсів і взагалі перехідним характером - від культури-post до культури-proto (за влучним спостереженням Ю. Ніколаєвської ${ }^{1}$ ). Ще однією методологічною ознакою сучасної музикології $\epsilon$ скерованість культури на виконавця, від якого чекають не стільки репродуктивної діяльності (за класичною формулою «композитор творець, суб'єкт першого роду; виконавець - суб’єкт вторинний, медіатор інформації для інших»), скільки креативного мислення, від якого залежить прикінцевий результат слухацької прагматики. Ідеться про співтворчість як сумісний процес звукообразного моделювання: творення-твір-інтерпретація-сприйняття. Когнітивна ситуація навколо усвідомлення цього процесу й, відповідно, його музичного продукту (твору та його інтерпретації) вивчається у світлі вже усталеної наукової дисципліни «інтерпретологія», яка стрімко набирає обертів у системі музичної освіти України.

Які ментальні принципи характеризують музикознавчу думку на момент відокремлення вітчизняної науки від радянської державної системи (1991 рік)? Як відомо, генетично історія музикознавчої освіти в СРСР розвивалася під гаслом цілісного аналізу, який визначав пріоритет змісту над формою (за гегелівською максимою «зміст дорівнює формі; форма є зміст»). Постать музиканта-виконавця в межах цього підходу завжди малася на увазі (ішлося про виконавські засоби виразності, про роль геніальних виконавців і педагогів). Утім перевага дослідницької уваги була все ж таки на боці композитора як творця музичного твору. Твір був предметом аналізу в різних аспектах його організації та буття.

Не можна вважати, що інтерпретологію цікавить не композитор, а тільки «реалізатор» чужої творчої продукції (це було б механістичним розподілом функцій, яке неможливе в мистецькому або дослідницькому акті). Дійсно, особистість інтерпретатора в сучасній комунікації відіграє «першу скрипку». Утім $є$ проблема, яку точно відзначив композитор

\footnotetext{
${ }^{1}$ Ніколаєвська Ю.В. Ноmо Interpretatus в музичному мистецтві XX-XXI століть : монографія. Харків : Харківський нац. університет мистецтв імені І.П. Котляревського, 2020. С. 474.
} 
Д. Малий, котрий вивчав роль концептуалізму в системі категорій композиторського мислення: «... наскільки чітко можна теоретизувати аналітичні форми (те, що можна «виміряти»), настільки незрозумілі бувають змістовні (ідеї, концепти, інтонації тощо). Неоднозначним $\epsilon$ контекст їх виникнення і «буття» у свідомості художника. У цьому полягає вся складність дослідження процесів композиторського мислення як предмета наукової дискусії в сучасному музикознавстві» ${ }^{2}$. Наслідком ускладнення процесу відтворення композиторської концепції, що залежать від типу художньої свідомості митця (філософський, релігійний, науковий) i «привертає увагу публіки свіжим ставленням до звуку в інструментальних, симфонічних i вокально-хорових жанрах, тонким тембровим письмом, широтою філософського мислення, одним словом концептуальним підходом до творчості» ${ }^{3}$, постає нова виконавська поетика, яка, власне, вміщує суголосну творчість композитора й виконавця та яка становить духовну-семантичну значущість для слухача.

Мета дослідження - обгрунтувати фундаментальну єдність теорії i практики як методологічної платформи процесу виховання музикантавиконавця та розвитку особистості інтерпретатора в глобалізованому світі.

\section{1. Методологічні засади дослідження музичного твору як суб'єкта.} «Особистість - мислення - свідомість» у системі інтерпретації

70-ті роки минулого століття - доба панування семіотичного підходу, який став умовою наукового опису музичних явищ, опрацювання твору як тексту. Через аналіз окремих елементів музичної мови/мовлення (школа Б. Яворського, Ю. Тюліна, Л. Мазеля-В. Цуккермана) йшов процес опанування цінностей музики як мислення (праці межі двох тисячоліть М. Бонфельда, В. Москаленка та ін.) і, навіть більше, музики як аналога людини й смислової моделі буття. Текст не є психічною реальністю, уважав М. Арановський ${ }^{4}$, тому що тільки мовлення наділено людськими інтенціями, оскільки належить людині-творцю й передає від нього емоційну та інтелектуальну інформацію іншим. А хто творить живу, духовну реальність? Власне, виконавець, який інтерпретує композиторський твір як власний продукт художньої свідомості, він іiі примножує, додає дихання й «уживає» в самосвідомість культури за принципом моделювання універсальних законів музичного твору, його буття як духовної реальності 5 .

\footnotetext{
${ }^{2}$ Малий Д.М. Специфіка композиторського мислення в музиці останньої третини ХХ - початку XXI століть : автореф. дис. ... канд. мистецтвознавства : 17.00.03 «Музичне мистецтво». Харків, 2018. 18 c.

${ }^{3}$ Малий Д.М. Специфіка композиторського мислення в музиці останньої третини ХХ - початку XXI століть : автореф. дис. ... канд. мистецтвознавства : 17.00 .03 «Музичне мистецтво». Харків, 2018. $18 \mathrm{c}$.

${ }_{5}^{4}$ Арановський М. Музыкальный текст. Структура и свойства. Москва : Композитор, 1998. 343 с.

5 Шаповалова Л.В. Духовная реальность музыкального произведения и методы ее анализа. Проблеми взаємодї мистецтвва, педагогіки та практики і теорії освіти. Вип. 40 : Когнітивне музикознавство. Харків : Харківський національний університет мистецтв імені І.П. Котляревського, 2014. C. 11-32.
} 
Якщо мислення відповідає за логічні процеси творення та відтворення звукових структур у звукообразному мистецтві, то інтерпретологія акцентує увагу на причинах мислення homo creator'a - його свідомості, відшукує нові смисли та акценти особистісного бачення себе і світу в дзеркалі «семіотичних ландшафтів», що являють собою сумарний «текст культури» (причому не лише музичної, а синтезованої, укупі з усіма поетичними, художніми видами творчості). Перед дослідником музики постає дилема: на що спиратися у своїх розвідках «чужого досвіду»? Де лежить «точка відліку» суджень та уявлень про сутність музики? Для інтерпретатора відповідь очевидна: точкою відліку є я сам, мій досвід, моє бачення; і я маю розвивати своє мислення, свій розум, удосконалювати свій слух, серце, усі музичні навички, щоб бути відповідним до музикантів-творців вищого світу мистецтва. Ось так формулюється завдання для сучасного виконавця. Тому формування мислення виконавця - це комплексне завдання в єдності новітньої практики музикування (творення та відтворення) і теорії музики. Тому надметою $\epsilon$ визначення статусу теорії музики, яка забезпечує фундаментальність функціонально-структурних засад мислення виконавця (homo musicus). Набутий досвід, що належить суб'єкту-виконавцю, який осмислює закони музичного мислення як творчого буття, переходить від предметностей теорії музики (твір-мова-текст-зміст-розуміння) до досвіду їх інтерпретації. Засадничим методом інтерпретології є рефлексія в значенні психологічного механізм самопізнання Я-особистості музиканта.

Серед системних рівнів художньої цілісності в музиці найвищими $\epsilon$ функціонально-структурний та інтонаційно-стильовий. Кожний із них $\epsilon$ носієм специфічного мислення. Виокремимо два рівні інтерпретологічного аналізу твору - структурно-мисленнєвий (у «згорнутому вигляді» в ньому наявний весь мовний комплекс стилю композитора) та жанрово-стилістичний (виконавський склад, установка свідомості на усталені моделі й особистісний «резонанс» на досвід традиції). Їх взаємодія становить концептуальний аспект пропонованої статті.

Формування мислення виконавця - це комплексне завдання в єдності новітньої практики музикування (творення та відтворення) і теорії музики. Тому в статті ставиться за надмету визначення статусу теорії музики, яка забезпечує фундаментальність функціонально-структурних засад мислення homo musicus. Набутий досвід, що належить суб'єктувиконавцю, який осмислює закони музичного мислення як творчого буття, переходить від предметностей теорії музики (твір-мова-текстзміст-розуміння) до досвіду їх інтерпретації. Засадничим методом інтерпретології $\epsilon$ рефлексія в значенні психологічного механізму самопізнання $Я$-особистості музиканта. 
Композитори своєю авторською рефлексією являють світу власну, виправдану особистісним зусиллям міру входження в сутність Буття. Відмова від вузького, егоцентричного розуміння мети музичного мистецтва (на кшталт «самовиразу») привела до відкриття синергійної парадигми мистецтва як рефлексії на світ: від міжособистісної інтонації спілкування, незамкнутої на собі сповідальності - до способу самопізнання й Богоспілкування. Отже, стара академічна наука не займалася проблемами трансформації свідомості. Натомість інтерпретологія висвітлює акценти виконавської рефлексії на композиторський твір, який віддзеркалюється в свідомості іншої особистості, Іншого покоління слухачів та історичного часу. До того ж інтерпретологія «не зациклюється» на перевагах музики класико-романтичної доби, тоді як практика XX століття до сих пір уважається «terra incognito» й недостатньо зрозумілою для широкого загалу слухачів. Тому саме виконавці стають «теоретиками» власної феноменології творчості.

Через що виникає складність виховання мислення музикантавиконавця? Через трансформацію звукообразних засад творчості у творчій практиці XX ст. Відношення до звуку та форм і засобів його вибудування - «загальне місце» в роздумах багатьох дослідників. Звідси новий зміст основних категорій виконавської поетики: змінюється мелос і завдання його інтонування; трансформуються засади музичної форми й техніки композиції.

Відмінності в техніці письма композиторів є продуктом мисленнєвої парадигми, зумовленої художньою свідомістю. Взаємозумовленість світогляду й техніки композиції полягає в способі композиторського мислення - його мінливості, структурності, детермінізмі одних процесів і дискретності інших.

Композиторське мислення як динамічна система підпорядковує процес формування виконавського мислення, яке $є$ неодмінним складником музичної комунікації. Якщо митець не знайде «спільну мову» 3 виконавцем, не «підніме» його до свого рівня, унеможливлюється зустріч музичного твору зі своїм слухачем. М. Бонфельд розрізняє «мислення музикою» - специфічний різновид невербального мислення, при якому музика вирізняється як суб'єкт мислення, пов'язаного 3 музичним мовленням», ${ }^{6}$ і «музичне мислення» - як «різновид художнього мислення» ${ }^{7}$. Процеси розумової діяльності індивіда, вступаючи в діалектичні зв'язки 3 компонентами музичної мови, утворюють внутрішню єдність.

У процесі мислення відбувається мислення не просто музикою, а й оперування всіма компонентами музичної мови (мелодикою, ладо-

${ }^{6}$ Бонфельд М.Ш. Музыка: язык, речь, мышление. Санкт-Петербург : Композитор, 2006. С. 128.

${ }^{7}$ Бонфельд М.Ш. Музыка: язык, речь, мышление. Санкт-Петербург : Композитор, 2006. С. 128. 
гармонічними комплексами, метро-ритмом, фактурою). Утворюючи логічні зв'язки між собою, вони реалізуються в кінцевий продукт розумово-світоглядної діяльності композитора - музичний твір. Він, у свою чергу, стає суб'єктом нової духовної реальності.

Метод пізнання визначає стратегію творчості, іiї спрямованість. Через слово, інтонацію, музику відбувається пізнання духовної реальності музичного твору. Якщо структура слухацького сприйняття звукової структури (за Є. Назайкінським, містить три рівні (елемент - синтаксис композиція) $)^{8}$, то інтерпретологія пропонує інший алгоритм тлумачення музичного твору з погляду мислення виконавця: починаючи від вищої точки ціннісної семантики (смислу як цілого) - через ототожнення 3 духовно-психологічним досвідом Іншого (Я-автора=Я свідомості музики) і до відтворення музичного твору як нової реальності, яка стає Дарунком Іншому - слухачеві від Автора. Так складається рефлексивне коло спілкування духовних двійників: автор=інтерпретатор=адресат (слухач).

Метарівень музичного діяння людини становить Бог, Небо; серце; Божий світ, краса, проявлена через духовне бачення; розкривається він через інтонацію псалмодії (див. нижче аналіз першого псалму А. Шнітке). Рівень нижче в синергії музичного спілкування - дух людини (внутрішня людина, за Біблією), дія якого йде через енергії та вербально-поетичний ряд символів (світло, серце, шлях до істини, життя як Богоспілкування, Віра, Надія, Любов).

Музика розкриває довічний зв'язок душевного й тілесного (психосоматика); «музика - це не чисто земне явище. У неї є містична глибина», за В. Медушевським9. Тому третій рівень - душа людини (homo animus), яка від Христа має розум; ії зростання спрямоване в небо. У житті душі спостерігається єдність свідомого і несвідомого, рефлексивного (того, що людина може осмислити) i таємничого (метафізичного). Життя душі не вичерпується понятійним змістом (словом), він відкритий для таїни, чуда.

Після того як виконавець досяг (у Я-свідомості) рівня розуміння цілого й відчув свою внутрішню тотожність цінностям музичного спілкування, він опрацьовує рівні реалізації свого модусу в реальний часопростір гри-відтворення «живого тексту». Перший його рівень - це знаки-першоелементи як вираження явленого Буття: праінтонації, ритмоінтонації, ладогармонічні звороти, темброкомплекси, де в концентрованому («згорнутому») вигляді міститься краса як символ, що відкриває вікно у світ невидимий.

Другий рівень виявляє себе в музичному творі як відносно закінчений, композиційно оформлений смислообраз (експозиція), що виростає 3

\footnotetext{
${ }^{8}$ Назайкинский Е.В. О психологии музыкального восприятия. Москва : Музыка, 1972. 383 с.

${ }^{9}$ Медушевский В. Духовный анализ музыки. Москва : Композитор, 2014. С. 113.
} 
першоелемента (мотив, звукоформула, тема). Оскільки символ - явище динамічне, його подальше «проростання» в музичній формі вже не пов'язане з іманентно-музичним синтаксисом. Символізація найяскравіше виявляється на третьому рівні аналізу смислообразів, де осмислюється спрямованість розвитку - тип музичної драматургії (з урахуванням світовідчуття homo animus, психологічного і драматичного модусів, життя серця - ліричний усесвіт).

\section{2. Від тексту до інтерпретації: аналітичні розвідки}

Матеріалом для дослідження засад структурного й інтонаційностильового мислення в сучасній музиці, яка вимагає від виконавців відповідного рівня адекватного розуміння та відтворення у власній творчості, обрано зразки з новітньої творчої практики. У них шукаємо відповідь на головне питання музикознавчого дискурсу: які стильові тенденції $є$ пріоритетними й зумовлюють інтерпретативний підхід до вивчення композиторського мислення? Домінуючими в ціннісносемантичному плані, на наш погляд, $\epsilon$ ті образно-жанрові сфери творчості, які виявляють:

- пошук опори в конфесійних скрижалях Буття (неолітургічну сферу буде проаналізовано на матеріалі гімну I з циклу А. Шнітке «Гімни»: див. приклад 2).

- тему самотності людини в ії екзистенціальному наверненні; звідси медитативна музика як один із пріоритетів буття внутрішньої людини: цей тип розглянемо на експозиції циклу «Пісень 3 Китаю» ор. 58 Б. Бріттена (див. далі приклад 1) та інструментальної композиції Д. Капиріна «За течією» (приклад 3).

Отже, ми обрали два типи музичної семантики - медитативний i літургічний. Із позицій ціннісної семантики творчість лідерів авангарду музичної культури другої половини $\mathrm{XX}$ ст. має дещо месіанське значення: композитори актуалізують повернення релігійного мистецтва, усвідомлення національних коренів, духовної культури людства в цілому.

Алгоритм моделювання виконавцем художнього цілого, яке інтерпретується, постає як шлях сходження від одної структури до більш високої в межах єдиної стильової системи та залежить від:

а) ладогармонічної структури (модальні, тональні);

б) техніки опрацювання тематизму (мелодико-гармонічна, поліфонна, варіантна, комбінаторна);

в) співвідношення Часу та Простору в духовній реальності музичного твору.

Перейдемо до прикладів, які мають ілюструвати теоретичні підвалини композиторського мислення у взаємодії з виконавськими параметрами інтерпретативного аналізу. 
Приклад 1 підказав китайський співак Ці Мінвей, який познайомив харків'ян із рідкісним для сучасного українського слухача камерновокальним опусом 58 Б. Бріттена: ідеться про «Пісні з Китаю». Для багатьох відкриттям є його першовиконавці: гітара (Джуліан Брім) i тенор (Пітер Пірс). Цей твір сьогодні сприймається як репрезентація чи не найпершої «зустрічі Сходу та Заходу» у свідомості європейця. (Серед інших прикладів звернення композиторів XX століття до поезії епохи Тан - твори А. Веберна, Г. Свиридова, Е. Денисова, О. Рудянського).

Виконавський склад твору $є$ унікальним: гітара здатна слугувати звуконаслідуванням китайського струнного інструмента піпи (споріднений до лютні). Незвичайна експресія тенорового співу інкрустована в сонологічну фактурну прозорість і філігранність тембрових звучань, що додають вишуканість східного колориту. Разом темброве вирішення (тенор і quasi-піпа) співзвучні уявленням композитора про живу поезію далеких часів із життя Китаю й первозданність як умову щастя прекрасного та недосяжного ідеалу-мрії про кращі світи, що «ховаються» у фантазіях та історичних мандрівках поета.

Звернімося до ладогармонічного аналізу двох п'єс, що становлять експозицію циклу (№ 1; 2) задля характеристики інтонаційно-стильового мислення британського генія в контексті моделювання іншої культури. Художня єдність шести мініатюр із програмними назвами, не пов'язаними загальним сюжетом, являє собою скоріше альбом із зовнішніх вражень і картин життя мандрівника. Хоча є виняток: «Депресія» (№ 5) «випадає» із загальної драматургічної «канви», належачи явно не до зовнішнього світу, а, скоріше, оголюючи автобіографічний мотив модної для «європейського декадансу» авторефлексії. Можна пунктиром намітити психологічну лінію, яка містить натяк на внутрішні переживання автора (№ 2; 4; 5).

Титульний образ циклу «Колесо фортуни» - це алегорія середньовічних уявлень про долю людини. Образ колеса створений за допомогою секвенціювання короткої теми активного характеру: «фігура колеса» (мотив $a$ в партії canto) - це поспівки в низхідному русі (від тонічної квінти до терції основної тональності $F$ ) із подальшим стрибком угору на чисту кварту (VI-й ступінь). Починаючись із характерної синкопи в нюансі $f$, вона звучить яскраво й «задерикувато», задаючи містичний тон, згідно з віруваннями давніх культур. Починаючись у F-dur міксолідійському, canto підхоплює фігуру «колеса» в лідійському «забарвленні» D-dur!. Фермата розділяє першу фразу від другої на відстані в.2 як умовне обертання колеса.

У гітарному тематизмі слух ясно розрізняє два фактурні плани: верхній - паралельні квінти, які виділяються артикуляційно; нижній ритмічна фігура шістнадцятих тривалостей, що то піднімаються вгору, 
то опускаються вниз - звукова «емблема» колеса. «Зсув» на нову звуковисотність відзначено нюансом ріапо (м'яко-душевна покірна відповідь людини на заклик долі), але з інтонацією тритону (зб. 4), що підсилює внутрішне напруження - відгонить дисонансом «метал» голосу Фортуни. Тема отримує метричну стійкість (із другої фрази звучить уже із сильної частки, хоча й подовженої за рахунок синкопи на «вісімках»). При цьому гітарні фігурки постійно варіюються темброво й ритмічно: висока, дещо «сухувата» теситура, і дзеркальні перестановки (обернення й ракоходи) значно оновлюють шлях «колеса».

Загалом для віршування старокитайської традиції характерною $\epsilon$ асиметрія, що відбивається на музичному синтаксисі, формуванні уявлень про час, його закони (відсутність у партії вокалу регулярної акцентності й постійне уникнення між партіями метро-ритмічної єдності, панування комплементарності). Так, експозиція першої вокальної мініатюри циклу утворюється як розімкнутий період із двох неповторних речень $(\mathrm{a}+\mathrm{b})$ неквадратної структури $(7+6)$. У партії гітари зупинка на домінанті «омінорює» терцію (as - замість $a$ ), немов відлуння вокальної інтонації. Можна було б потрактувати проведення двох тем як самостійні періоди (двочастинну безрепризну форму АВ). Однак ми схильні вважати, що для вокально-інструментального письма композитора, що інтонував англомовні вірші (переклад із китайської), характерним $є$ образний моноліт із дрібних будов, які пов'язані за контрастом семантичними зв'язками. Точно так і побудовано експозицію: а - образ колеса, в - суб'єктивна реакція людини.

Другий розділ теми Фортуни (т. 14), що будується на тому самому музичному матеріалі $\left(\mathrm{a}_{1}+\mathrm{b}_{1}\right)$, позначений секвенцією та поверненням тихої звучності. Терасоподібна мелодика, підіймаючись по акордиці $g$ moll і міксолідійського Es-dur'a, кадансує в A-dur (т. 19). У партії гітариста виникає дисонуючий підголосок за рахунок міксолідійської поспівки des-c-des-es-f на тлі терції тональності A-dur! Продовження теми в (тт. 21-26) надає приголомшливий ефект «секундового тертя» (від поєднання двох тональних центрів: A-dur у партії вокалу й Fis-durу гітари (т. 22).

Химерна ладо-тональна гра містить енгармонічну заміну (в т. 22 Fis $G e s$, розв'язка у $G$-dur), створюючи грунт для «зорових» асоціацій із невідворотністю навали Фортуни (тт. 25)! Ще один підйом теми в ( з A-dur'ної сфери на висоту E-dur) у кульмінаційній динаміці ff указує на динамічну репризу (з т. 27). Ключові слова «The big chariot» підкреслені найвищою теситурою $\left(g_{2}-f i s_{2}\right)$ і наступним низхідним рухом, що нагадує сміх. Стилістично репризу позначено новою якістю, а саме:

- трансформацією основної теми $\left(\mathrm{a}_{2}+\mathrm{a}_{3}\right)$ i відмовою від матеріалу другої фрази (в); • ладовою перемінністю (гра «мерехтливої» терції $a$-as); 
- ритмічним дробленням теми а з «гальмуванням» на висхідній кварті та тривалою зупинкою на дорійському ступені.

Міксолідійський тон es $_{2}$ «відводить» мелос униз по фрігійському звукоряду аж до тоніки $F$ («натяк на семантичну фігуру смерті). I рух зупиняється... Лише гітарні «баранці»-оспівування із шістнадцятих тривалостей, що символізують рух колеса, намагаються вирватися із фрігійської суворості на простір сонячного $F$-dur'a (т.42). Тритоновий «слід» хмаркою розчиняється в натуральному звукоряді третьої октави. Залишається лише здивування («... що це було?»).

Друга мініатюра «Стара лютня» (поезія Бо Цзюй I) являє «побічну партію» в драматургії циклу - це контраст жіночно-м'якої мрії про щастя на противагу маскулінно-енергійному «Колесу Фортуни». Повільно «пливе» спогад під звуки старої лютні в матовому гармонійнодисонантному серпанку про те, чим і як жило закохане серце. Цікаво, що ця мініатюра відкриваються не паритетним звучанням голосу і гітари (як у 1-му номері циклу), а інструментальним вступом гітари соло, як наслідування гри на лютні. Помітними жанрово-стильовими знаками «старої лютні» $є$ безліч сегментів інструментального тематизму, «спаяного» в поетичну аури статики: дисонантні опори гармонічної вертикалі (нони, септими); комплементарний ритм і поліритмія з вільно усередині варійованим малюнком великих тривалостей, де дихає «биття» дрібних шістнадцятих і тріолей; органний пункт на тонах $e$-fis (з елементами basso ostinato).

Верхній шар тематизму гітари теж варіантний за принципом sopranoostinato, надає музиці ауру казкової колискової, ірреального життя в напівсні. Мелодію соліста позначено авторською ремаркою «always and parlando». При виписаних при ключі знаках тональності $H$-dur партія canto обіймає амбітус іншої тональності: рухається вгору по звуках тонічного тризвуку E-dur, зачіпаючи висхідну кварту ais-dis і плавно спускаючись по низхідній гамі. Не відразу слух розуміє, що це лідійський мажор, настільки незвично (з погляду європейської тональної системи) сприймається мелос цієї мініатюри, зачаровуючи східним пленером, магією ритмотембрових діалогів.

За структурою в гітарній темі відчутна квадратність, що є типовим для інструментальної музики, орієнтованої на танцювальні рухи. Однак повільний темп і химерна ритміка вуалюють функцію дискретності. Щодо формоутворення можна говорити про варіації на basso-ostinato, тоді як ясно помітні риси простої двочастинної репризної форми $\left(\mathrm{a}+\mathrm{a}_{1}+\mathrm{B}+\mathrm{a}_{2}\right)$ виявляються «формою другого плану» (за Вл. Протопоповим). У репризі образ отримав внутрішню трансформацію: тема canto несподівано позбавлена звичної гітарної підтримки (перерване ostinato). Самотньо звучить замикання низхідної гами в заключному 
кадансі теми гітари; йому вторить у вільному польоті тенор (ремарка $a d$ libitum) і завмирає на $G$-dur'й інтонації в порушення закону тональної репризи.

Маленька кода виникає несподівано у швидкому русі тріолей (темп Quick), де кожна восьма - хоровод тридцятьдругих тривалостей $($ чверть $=104)-$ стверджує функції тоніки $G$ і домінанти $D$ навколо «розлому» - нової точки ладової опори. Зруйнована ілюзія «чужої» давнини (лідійський лад - знак архаїки) повертає свідомість до містичного стану, від інших світів - до реальності «тут і зараз». Якщо вербальний текст і містить пояснення звуконаслідування лютні, однак і без нього ефект виходу зі статики блискуче проілюстровано тембровосонористичним звучанням. Загалом кода робить композицію відкритою (терцієве зіставлення тональностей $E-G$ ). Тріольний рух асоціюється із сонячними відблисками, що розбудили своїм мерехтінням нічну млу i сходження героя усвідомлення Істини: $є$ й інше життя... Воно скрізь, лише треба душі зазирнути в глибини буття!

Приклад 2. Варінтність як конщепт структурного мислення та його иіннісна семантика. Розглядаючи музичний твір і його форму як живий організм, що постійно розвивається, необхідно розуміти не тільки специфічні закони (властиві творчим індивідуумам), а й універсальні, які завдяки своїй всеосяжності стають ключем до пізнання цієї специфіки. Розглянемо цю тезу на прикладі ідеї щодо втрати сонатністю своєї провідної ролі. Її значення як структурної парадигми класикоромантичного періоду європейської музики у XX столітті, після двох «Хвиль» авангарду, помітно зменшилося. На наш суб'єктивний розсуд, іiі місце посідає принцип саморозвитку, або саморозгортання, який отримав безліч специфічних проявів і теоретичних визначень, головний із яких - варіантність. Генезу варіантності варто вбачати не лише в поліфонічних формах доби середньовіччя та відродження в Західній Європі, а й у іiі спадкоємних зв'язках із романтичними традиціями слов'янської музики (зокрема української та російської, які виросли на грунті національно-пісенної культури). Варіантний принцип музичного розвитку прямо залежить від зміни історичних умов, які безпосередньо впливають на закономірності образного моделювання.

Варіантна форма, вступаючи в складні взаємини 3 іншими типами формотворчості, породжує різноманіття способів взаємодії/сполучення різних моделей звукообразного мислення, отже, постає як універсальна категорія творчого мислення в практиці XX ст. Зокрема, ідеться про здатність варіантності до моделювання взаємопереходів тонких музичних матерій, без контрастів і зсувів, як при сонатному принципі. Двосвіття зовнішнього та внутрішнього завдяки варіантним принципам розгортання/згортання постає як бажана переломність буття. Плинність і 
водночас монолітність часопростору при варіантних методах композиції відповідає внутрішнім потребам людини, яка рефлексує над тонкими моментами буття (від народження життя ідеї - до трагічних одкровень). Варіантне мислення як структурну закономірність варто вивчати саме виконавцям, які мають розумітися на шляхах іiї реалізації в різних жанрово-стильових контекстах.

Для аналізу варіантності обрані приклади, у яких варіантність унаочнює єдність образного ц̆ логічного мислення через наявність виконавських параметрів авторського тексту.

Перший Гімн із циклу «Гімни» А. Шнітке має варіантно-строфічну будову: 7 строф зі вступом і висновком. Розподілом між строфами слугує акорд arpegio на pizzicato, витриманий на ферматі. У драматургічно важливих строфах - 5-й (кульмінаційній) і 7-й (заключній) - він звучить тричі. Проводиться знаменний розспів не відразу - лише в 5-й строфі, формуючись поступово в процесі варіантного розвитку музичного матеріалу. Задіяний А. Шнітке принцип $є$ тотожним до структури знаменного розспіву, що також базується на грунті варіантного розгортання окремих поспівок, запозичених із системи осмогласія. Відповідно, 1-4 строфи - це рух до жанрово-стилістичної цитати, іiі довге, поетапне становлення символізує духовний шлях людини до Бога. Зміст вступу складається з трьох акордів-кластерів. Музичне становлення являє горизонтальне розгортання однієї лінії цього багатоголосся. Важливо відзначити інтонаційні «осередки» акордів: секунда (мала, велика, збільшена), кварта (чиста, збільшена) і терція. Конструктивна графіка відрізняє партію арфи: два квартсекстакорди $\left({ }_{4}^{6}\right)$ звучать у противорусі по м. 2, у контрапункті з целотоновими ходами литавр. Варіантно-лінеарний розвиток, заснований на заданому тематичному комплексі, і функціональна ясність притаманні всім чотирьом Гімнам циклу.

Тема гімну базується на простій мело-формулі, що є основою багатьох культових наспівів. Трихорд $(c-d-e)$ звучить інтонаційно як новий за рахунок граничної хроматизації кожного тону. Трихордові звороти виявляють спорідненість із закономірностями російської співочої культури. Спочатку задані параметри є основою варіантних поспівок, які шикуються в ланцюг плавного недискретного розгортання тематизму, «завоювання» все нових інтонацій, на грунті послідовного варіантного проростання.

Робота А. Шнітке 3 інтонацією цілком відповідає властивостям варіантного методу. Відбувається процес «намацування» первісної інтонації, народження зі «звукового хаосу» (прима, секунда, дві секунди тощо). Кожна інтонація відокремлена ферматою й сама по собі діатонічна (тт. 3-5), але сумарно вся мелодійна лінія являє собою хроматичний звукоряд в обсязі збільшеної кварти (тт. 3-8). При цьому 
А. Шнітке спирається на принцип поступового розширення діапазону за рахунок задіяння секунди спочатку знизу, потім зверху. Далі відбувається наче «руйнування» інтонації наспіву за рахунок вібрато та «сповзання» по чвертьтонах.

Організація звукоряду (як у першій строфі, так i в наступних) спирається на принцип, який властивий православному церковному співу: у висхідному русі всі звуки повинні підвищуватися, у низхідномузнижуватися. Разом із тим за допомогою варіантного розвитку здійснюється пошук опори для об'єднання всіх голосів в унісон. I така опора для перших чотирьох строф - звук «е» - нарешті встановлюється (див. т. 8).

Принцип варіантного розвитку поєднується 3 поліфонічними прийомами: у тт. 6-8 спостерігаємо одночасне проведення теми в кількох варіантах: в основному, у збільшенні, з імітацією (у литавр). Опора на поліфонію невипадкова: вона виконує функцію зведення воєдино всіх голосів, створює ефект храмового виконання наспіву.

Уже в першій строфі слух стикається із ще однією цікавою властивістю варіантного принципу: тотожність закінчень варійованих побудов. У мелодичному кадансі виокремлюється ритмоформула oddloddlo, характерна для висновку кожної строфи (тт. 12-13, 20-21). Заключний зворот, оформлений ідентично звуковисотно й ритмічно (висхідна ступенева інтонема, спрямована до устою), - це жанрова ознака знаменного розпіву.

При цьому виявляється одна характерна особливість: схожість збільшується в міру наближення до кінцевого тону, періодичність формується 3 кінця й не отримує структурного відмежування від попереднього матеріалу. Періодичність кадансових ділянок слугує фактором становлення варіантно-композиційних зв'язків. При цьому в структурі гімну № 1 виявлено повторність мелодичних кадансів як засіб маркування (знаменита теза X. Римана про «повторення, що об'єднує»).

У Гімні № 1 можна розрізнити два різновиди структурно-інтонаційного проростання (від «ядра» - до цілого): 1) дискретне, відмежоване всередині варіантних змін; 2) недискретне, із цілеспрямованим процесом варіантних накопичень. Обидва принципи становлять сутнісні ознаки варіантного методу. Проаналізуємо будову 1-ої строфи Гімну № 1 А. Шнітке.

Структура основного розділу - неквадратна (5 т. +3 т. +5 т.), що породжує подальшу композиційну асиметрію:

2 строфа $(3+5)+(3+5) ; 3$ строфа $(3+6)+(3+6)$;

$4,5,6$ строфи $(3+5)+(3+5)$.

Неквадратні структури підкреслюють еволюційний характер варіантної форми, при якому межа між експозиційним викладом і розвитком 
виявляється умовною. Якщо перша строфа характеризується тематичним розгортанням і нарощуванням масштабів побудов $(2+6+5+8)$, то друга обумовлена появою гетерофонних елементів (дублювання мелодичної лінії в терцію), опорою на тетрахорд і політональність. Підвищення регістра відбувається за рахунок зчеплення мотивів cis(c)-fis (1-a строфа) - fis- $h$ (2-a строфа). У першому і другому п'ятитактах ідентичні лінії литавр; у них легко впізнавана слухом секундова інтонація знаменного розспіву, яка стає остинатною формулою всіх строф (крім 1-ї). У цих будовах також збігаються закінчення (останні 2 такти в усіх голосах).

Якщо другий тритакт починає функцію розвитку (за аналогією 3 1-ю строфою) в загальній структурі п'єси: $\mathrm{AA}_{1} \mathrm{BA}_{2}, \quad$ то третя характеризується варіантними перетвореннями фактури на основі таких прийомів:

- підголосковості (у партії арфи);

- секвенції: точні (ц. 3 тт. 1-2) або зі зміною ланки (ц. 3 тт. 5-6, тт. 7-8);

- органному пункті (у партії контрабасу);

- трансформації трихорду у фігураційну будову 3 ідентичним мелодичним змістом (кожен звук представлений оберненим інтервалом і так звучить і розвивається протягом третьої строфи; див. нижній голос в Arpe);

- розшаруванням фактури на функціональні голоси-пласти (мелодична лінія у $V c$., імітаційний - в Arpe, остинатний - у Timp).

Четверта строфа будується на основі варіювання трихордових поспівок. Малосекундові гармонії (кластери) змінюються квартсептакордами, квартдецимакордами. Мелодиці притаманні тріольний ритм, синкопи, форшлаги із широкими інтервальними ходами. Між 4 i 5 строфами немає розмежувального акорду, що створює спрямованість мелодичного руху до кульмінаційної зоні - 5-ої строфи, у динаміці від $f$ до fff. Тема знаменного розспіву звучить двічі в литавр, причому друге проведення - з варіантними змінами; за рахунок прийомів продовженого розвитку спостерігається тенденція до укрупнення фраз $(2$ т. +3 т. +5 т. +11 т.).

Прийоми обернення, імітації, варіантних повторень, акцентування на кожній ноті повідомляють музиці динамічне, напружене звучання. Уперше з'являється тріольність, у кульмінації звучать кластерні акорди зі вступу, з тією самою інтонацією знаменного розспіву в партії Timp. і $з$ основною висхідною інтонацією у $V c$. у мажорному варіанті (у Гімні IV також триольність i кластери на більш високому емоційноузагальненому рівні).

6 строфа виконує функцію репризи: багатоголосне звучання теми в партії Arpe на тлі органного пункту литавр сприймається як нова 
цілісність: «тиха» кульмінація гімну, тема звучить у найвищому порівняно з іншими строфами регістрі. Уперше чітко виявлена вокальна природа - діатонічне триголосе звучання паралельними тризвуками на тлі органного пункту (h). Між шостою й сьомою фразами відсутній акорд, що розмежовує строфи, тільки невелике rit. підкреслює початок наступної строфи.

7 строфа - coda-післямова, соло литавр. Первісну тематичну конструкцію (що звучить вище на м. 6) перетворено: секундові ходи змінені; замість великих - малі навпаки). Тембр ударного інструменту руйнує вокальний первень; манера звуковидобування - щипок. Остинатно-секундове варіювання немов «гальмує» мелодичний розвиток, що закінчується на квінтовому устої (g-d). Обрамляють композицію Гімну № 1 вступні акорди.

Приклад 3. Проаналізуємо варіантний метод розбудови форми в п'єсі Д. Капиріна для саксофона-сопрано й камерного оркестру (15 інструментів) із програмною назвою «За течією». Поетичний епіграф (текст Хо Соккюна, Корея, кінець 18 початок 19 ст.) надає слухачеві установку на сприйняття музичного пейзажу, у якому звукообразна реальність самодостатня. Звукова матерія символізує саму себе - таїна, ключ до якого - у ньому самому.

Переклад поетичного образу в процесуально-звуковий «ландшафт» орієнтує свідомість, яка сприймає, на уявний об'єкт споглядання світу. Водний потік цікавить автора не сам по собі (з боку зовнішньої форми), а в усьому багатстві буття невидимого - глибинних символічних змістів (внутрішньої форми). Авторський задум виявляе множинність підтекстів. У скороминущому вбачається «життя без початку і кінця» (цитата 3 епіграфа: «Далек мой путь иль близок - все равно!») як одкровення переходу свідомості в інший вимір, або хронотоп. 3 одного боку, музично-просторовий символ «водного потоку» постає як увиразнення споглядального стану людини (психологічний шар твору). 3 іншого боку, ясно, що це лише перший, поверховий погляд, за яким уможливлюється більш глибинний зміст - відчуття Вічності. Перспектива показу метафізичної безкінечності видимого світу, який плавно перетікає у світ невидимий, є різноспрямованою. Річковий потік як «символ часу» репрезентований як рухома система координат із горизонтальними й вертикальними параметрами, що передбачає $\mathrm{i}$ зворотність часу, і можливий рух назад (наприклад, ракохідний рух, сформований за часи поліфонії строгого стилю). Така творча ідея повністю відповідає ціннісно-семантичним критеріям варіантного способу художнього моделювання. Ї̈̈ роль у формуванні композиційного процесу виявляється гостро затребуваною. 
Звукова ідея програмної композиції «За течією» міститься в зчепленні трьох тематичних блоків (тт. 1-3 партитури):

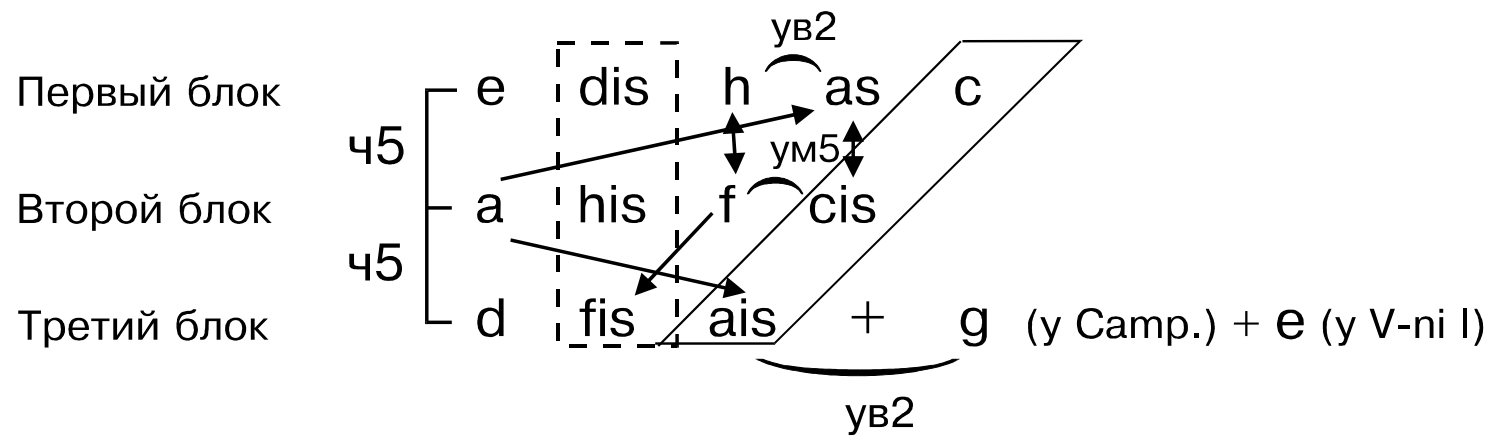

Схема унаочнює органічне сполучення тематичних блоків. Варіантність утілюється на рівні тоново-інтервальних співвідношень. Задіяні всі 12 тонів (без повторення). Вибудовується серія: e dis h as c a cis $f \mathrm{~g}$ fis ais $d$. Принцип заповнення тематичних будов до 12 тонів зберігається протягом усієї п'єси.

Перший секундовий мотив e-es $(C l$.) зчіплюється 3 іншим «h-as-c» (Fl.), утворюючи єдиний блок, від якого залишаються («зависаючи») три тони: $e$, es (dis) $c$ (V-no II, V-la, и Vibr). Із цих тонів згодом звучить лише dis: із його допомогою здійснюється зчеплення 3 наступним блоком $a$-cis-f, рівним за звучанням збільшеному тризвуки. Далі спостерігаємо інверсію першого мотиву «f-fis» $y$ партії кларнету $C l$., яку підхоплює $V c$, також «зависаючи». Водночас із тоном fis з'являється тон ais у V-lo II та на вісімку пізніше - тон dis, що залишився від першого блоку й потім глісандує в тон $d$. Так утворюється ще один збільшений тризвук «d-fisais» (кінець т. 3), а у верхньому регістрі у дзвіночків і $V$-nо I велика секста «g-e»- варіант терцієвого ходу всередині тематичних блоків.

У модифікаціях варіантної форми велику роль відіграє звуковисотний параметр. Позначимо інтервальний склад першого тематичного блоку, 3 якого виростають усі варіантні структури програмної композиції:

1-й мотив - e es (dis);

2-й мотив - h as c (або h c as);

3-й мотив (пасивний) $-h c$-інверсія 1-го;

4-й мотив (пасивний) - e as c - варіант 2-го;

5-й мотив (пасивний) - es h c - ракоход та інверсія 2-го.

До цього додається нова комірка - тритон a-dis (т. 2 в партії віброфона $(+C$-basso $)+$ педаль в альта). Разом зі збільшеним тризвуком, наявним ще в першому блоці (4-й пасивний мотив), тон dis утворює сталий гармонічний комплекс «a dis $f$ cis». Отже, тематизм композиції та його інтервальний склад є заданим (тт. 2-3). Усередині цієї заданості спостерігаються складні логічні зв'язки, засновані на варіантному 
принципі (див. схему вище). I надалі первісна інтонаційноконструктивна будова слугує основою композиції, завдячуючи різним варіантним модифікаціям цієї основи.

Велику роль має прихована поліфонія. У цьому прикладі - це рух по секундових ходах (частіше малих), що утворюється безпосередньо або на відстані. Розглянемо роль цього прийому на матеріалі експозиції.

Перша лінія - e es (т. 1 у Cl.), f-fis (у Fl., підхоплює $V c$. т. 2-3).

Друга лінія - $h c$ (т. 1 у Fl.), cis (у $P$-no., т. 2).

Третя лінія - as (т. 1 у Fl.), ais $h$ (у $P$-no II., т. 3-4).

Аналогічні лінії простежуються майже на всіх етапах варіантного становлення звукового матеріалу. Наскрізні інтервальні структури ніби «проростають» із первісного ядра в процесі розгортання всередині гармонічних будов. Так, другий тематичний блок на початку твору звучить як малий мажорний квінтсекстакорд із підвищеною квінтою $a$ es (dis) $f$ cis. За допомогою обернень, суміщень 3 іншими структурами, а також можливостей інструментування (виділення окремих тонів i нівелювання інших) утворюються нові структури, фонічно споріднені до пізньоромантичної стилістики.

Кілька прикладів із партитури ${ }^{10}$ : т. 3 ц. 3 - останні звуки квінтолі утворюють D7 (от $a$ ) $з$ пониженою квінтою $e s$ у $C l$. і секстою $f$ в $O b$. Найбільшу схожість із зазначеним вище акордом цьому співзвуччю надає щільний бас $a$ в Arpe, тон $g$ у $F g$, а також виразна лінія у $F l$. $C$-cis із «зависаючим» у вібрафона тоном cis. Надалі прозвучить варіант цього співзвуччя від $d$ (ц. 3; бас у Piano): він має більшу тривалість звучання й певний тональний «натяк» завдяки виділеному тембром мідних інструментів тритону c-fis. Аналогічні явища спостерігаються й надалі (т. 3 ц. 4, т. 4 ц. 5). Типові приклади варіантності всередині сталого гармонічного комплексу: тт. 3-4 ц. 6, тт. 1 ц. 7.

Отже, варіантність в інструментальній п'єсі Д. Капиріна базується також на принципі ритмічної нерегулярності: відбувається перетворення часового параметра - чергування ритмічних фігур (тріолей, квартолей, квінтолей) i їх комбінацій, які співпадають по вертикалі в усіх інструментів ансамблю. На рівні цілісної драматургії варіантність виявлена також завдяки «тембровим модуляціям»: від інструментів із певною звуковисотністю до ударних інструментів із невизначеною висотою звука або ударним прийомам гри на звуковисотних інструментах (і навпаки). Ці переходи здійснюються за допомогою різних прийомів звуковидобування (ц. 29). Наприклад, pizzicato, col legno у струнних; slap і гра на клапанах у духових, а також гра смичком по краю тарілок у поєднанні з високими флажолетами в струнних і

\footnotetext{
10 Див. партитуру. URL: https://www.musicaneo.com/ru/sheetmusic/4112_dmitrij_kapyrin/ (дата звернення: 17.07.2020).
} 
акордами в духових. Отже, варіантність володіє широким діапазоном прояву в музичній творчості, зачіпає як первинні мікроструктури, так i великі плани.

\section{ВИСНОВКИ}

Інтерпретологія як «точка відліку» для виконавця становить комплекс методів вивчення музичної творчості як персонально-сукупної рефлексії. Після визнання думки про суб'єктність музики, яка здатна вибудовувати духовну реальність (а не просто віддзеркалювати якусь дійсність), стало ясно, що тепер теоретизувати можна не текст, а духовну реальність, яка стоїть за цим текстом. У структурі виконавського мислення має бути закладеною ісрархія рівнів «розкодування» змісту заданих тематичних побудов як художнього цілого (за принципом «звук - отос - логос» як «слухом чую - розумію природу - відтворюю за допомогою виконавського апарату»).

1. Твір Б. Бріттена привернув увагу як один із прикладів інтуїтивного проторення «стежечки» до майбутнього звороту європейської еліти до глобалізації через звернення автора до символіко-поетичного мислення стародавнього Китаю. Зрозуміло, що вищим рівнем є стиль виконання, який має бути адекватним авторському тексту, з одного боку; з іншого вміщувати нову психологічну реальність - особистість виконавця (-ів), без феноменальності якого унеможливлюється художнє відкриття інтерпретації. Ця теза продемонстрована на прикладі першовиконавців «Пісень з Китаю» Б. Бріттена (Пітер Пірс і Джуліан Брім).

2. Структурний рівень моделювання виконавського мислення розглянуто на прикладі універсалізму варіантної техніки в музиці другої половини XIX століття. Ї̈̈ взаємодія з іншими принципами тематичного розвитку, розмаїття образно-композиційних рішень - ці ознаки свідчать про усвідомлення проявів варіантності як метода мислення. Як з'ясувалося, варіантний метод - ідеальна модель для символічного мислення 3 його двосвіттям («світ-Людина» та «людина - Бог») та асоціативно-плинною органікою. На прикладі Гімну № 1 (із циклу «Гімни») А. Шнітке виявлено орієнтацію автора на мелос знаменного розспіву, який слугує жанрово-стильовою моделлю для музики літургійної традиції. Аскеза молитовного гімну та внутрішня сила музики А. Шнітке споріднені єдиним світовідчуттям. На той час це було майже подвигом, але не поодиноким: таку саму місію підтримували у творчості багато митців (лідерами внутрішнього супротиву були Г. Свиридов, А. Пярт, В. Бібік і багато інших).

Релігійний тип мислення спирається на жанрово-стилістичні моделі традиційної культури відповідної конфесії як підгрунтя спадкоємності минулого й теперішнього, новаційно їх переосмислює. 
3. Аналіз варіантності в інструментальній композиції «За течією» Д. Капиріна виявив більш складну семантику та жанрово-стилістичну неоднорідність. 3 одного боку, очевидною є роль авторської установки на медитативність (в уявленні сучасного європейця); звідси музична символіка, рефлексія з приводу філософського змісту буття. Без конструктивної основи в такій звукотворчості не обійтися. Варіантність пронизує всі композиційні рівні цілого (i:m:t), усі параметри організації (звуковисотної, метроритмічної, фактурно-тембрової, артикуляційної). Структурні закономірності утворені як результат варіантнополіфонічного розвитку. Вплив варіантності на систему функціональних рівнів твору виявив граничну раціоналістичність композиції, винахідливість у комбінуванні різних тематичних блоків. За допомогою варіантного методу композитор досягає максимальної взаємодії елементів художнього цілого, безперервного оновлення композиційного процесу. Довершеність конструкції досягається завдяки вмінню обирати мінімум матеріалу й майстерно з ним працювати.

Безумовно, обрані приклади творів Б. Бріттена, А. Шнітке, Д. Капиріна не розкривають усієї складності проблеми та системності інтерпретологічного пізнання світу сучасної музики. Однак методологічні важелі, які містяться в постановці проблеми формування виконавського мислення, уважаємо конструктивними й такими, що мають перспективу наукового обговорення науковою спільнотою. Серед цих важелів насамперед назвемо:

1) установку особистості виконавця на рефлексивну структуру Я-свідомості, які ототожнює себе Іншою свідомістю - автора-творця - і суб’єктом самої музики; звідси роль феноменології особистості;

2) роль теоретичних принципів музичного мислення (звуковисотної структури, принципів розвитку заданої конструкції, тембро-фактурний комплекс, зумовлений саме виконавським складом тощо).

Отже, теорія музики збагачується виконавсько-психологічними чинниками сприйняття нової духовної реальності, яку творить інтерпретатор музики (інтенції волі, любові, суголосся людини зі світом). «Точкою відліку» в пошуках власної концепції виконавець має усталену систему інтегративних зв'язків теорії музики та їі сучасної «гілки»-інтерпретології.

\section{АНОТАЦІЯ}

Дослідження присвячене обгрунтуванню фундаментальних засад музичного мислення в композиторській практиці як методологічної платформи процесу виховання музиканта-виконавця в глобалізованому світі. Специфіку наукових уявлень щодо мислення сучасного виконавця узагальнює сучасна «гілка» теоретичного музикознавства - iнтер- 
претологія. Методологічними «скрепами» вивчення нової дисципліни слугують установка особистості на рефлексивну структуру Я-свідомості, яка ототожнює себе Іншою свідомістю (автора-творця та суб'єктом самої музики); роль теоретичних принципів музичного мислення (звуковисотності, принципів розвитку заданої конструкції, темброфактурний комплекс, зумовлений виконавським складом тощо). Проаналізовано маловивчені твори Б. Бріттена («Пісні 3 Китаю»), А. Шнітке (гімн I із циклу «Гімни») і Д. Капиріна (інструментальна композиція «За течією») як зразки втілення ціннісної семантики двох типових сфер композиції (літургічної та медитативної) у творчій практиці останньої третини XX століття.

Інтерпретологія як «точка відліку» для виконавця становить комплекс методів вивчення музичної творчості як персонально-сукупної рефлексії. Зроблено висновок, що в структурі виконавського мислення має бути закладеною ієрархія «розкодування» смислів художнього цілого (за принципом «звук - онтос - логос» як «слухом чую розумію - відтворюю»). Вищим рівнем $є$ стиль виконання, який має бути адекватним авторському тексту, з одного боку; з іншого - уміщувати в собі нову психологічну реальність - особистість виконавця, без феноменальності якого унеможливлюється художній сенс інтерпретації. Структурний рівень моделювання виконавського мислення розглянуто на прикладі універсалізму варіантної техніки в музиці другої половини XIX століття. Ї̈̈ взаємодія з іншими принципами тематичного розвитку, розмаїття образно-композиційних рішень - ці ознаки свідчать про усвідомлення проявів варіантності як метода мислення.

\section{ЛIТЕРАТУРА}

1. Арановський М. Музыкальный текст. Структура и свойства. Москва : Композитор, 1998. 343 с.

2. Бонфельд М.Ш. Музыка : язык. речь, мышление. Санкт-Петербург : Композитор, 2006. 647 с.

3. Капырин Дмитрий. URL: http://www.capyrin.com/Russian.html (дата звернення: 17.07.2020).

4. Малий Д. Специфіка композиторського мислення в музиці останньої третини XX - початку XXI століть : автореф. дис. ... канд. мистецтвознавства. Харків, 2018. 18 с.

5. Медушевский В. Духовный анализ музыки. Москва : Композитор, 2014. $420 \mathrm{c}$.

6. Назайкинский E.B. O психологии музыкального восприятия. Москва : Музыка, 1972. 383 с. 
7. Ніколаєвська Ю.В. Ноmo Interpretatus в музичному мистецтві XX-XXI століть : монографія. Харків : Харківський нац. університет мистецтв імені І.П. Котляревського, 2020. 572 с.

8. Шаповалова Л.В. Духовная реальность музыкального произведения и методы ее анализа. Проблеми взаємодії мистецтва, педагогіки та практики і теорії освіти. Вип. 40 : Когнітивне музикознавство. Харків : Харківський національний університет мистецтв імені І.П. Котляревського, 2014. С. 11-32.

\section{Information about authors:} Aleksandrova O. O.,

Doctor of Arts, Associate Professor, Head of the Department of Music and Instrumental Teacher Training

Kharkiv Humanitarian and Pedagogical Academy of the Kharkiv Regional Council 7, lane Rustaveli, Kharkiv, 61001, Ukraine

Shapovalova L. V., Doctor of Arts, Professor, Head of the Department of Interpretology and Analysis of Music Kharkiv National University of Arts named after I. P. Kotlyarevsky 11/13, Constitution sq., Kharkiv, 61003, Ukraine 